\title{
PERAN KELOMPOK AKSI PELAJAR ANTI NARKOBA DALAM UPAYA PENANGGULANGAN PENYALAHGUNAAN NARKOBA
}

\author{
Natal Kristiono, Indri Astuti, Hanik Latifah, Gustin R. P. \\ Universitas Negeri Semarang
}

\begin{abstract}
Info Artikel Abstrak
Sejarah Artikel:

Disubmit: September

2020

Direvisi: Oktober 2020

Diterima: November

2020

Keywords:

Abuse; Drugs; Student

Penyalahgunaan narkoba menjadi masalah yang belum bisa teratasi. Untuk menyelesaikan masalah penyalahgunaan narkoba tidak hanya bisa diselesaikan oleh salah satu pihak saja. Saat ini banyak pihak baik dari pemerintah, mahasiswa, maupun LSM yang telah menyuarakan dan peduli dengan masalah narkoba ini namun ini belum bisa mengatasi permasalahan tersebut Berdasarkan uraian dalam latar belakang maka permasalahan yang akan diteliti adalah: (1) KAPA Narkoba Sebagai wadah organisasi Pembinaan Pelajar, (2) Bagaimana upaya KAPA Narkoba dalam mencegah penyalahgunaan narkoba di kalangan pelajar Kabupaten Pemalang? Penyalahgunaan narkoba adalah penggunaan di luar keperluan medis, tanpa pengawasan dokter dan merupakan perbuatan melanggar hukum. Penyalahgunaan narkoba merupakan suatu proses yang makin meningkat dari taraf coba-coba ke taraf penggunaan untuk hiburan, penggunaan situsional, penggunaan teratur sampai kepada ketergantungan.
\end{abstract}

\begin{abstract}
Drug abuse is an insurmountable problem. To solve the problem of drug abuse can not only be solved by one party. Currently, many parties, both from the government, students, and NGOs, have voiced and cared about this drug problem, but this has not been able to solve the problem. . (2) How is KAPA Narkoba's efforts in preventing drug abuse among students in Pemalang Regency? Drug abuse is use outside of medical purposes, without medical supervision and is an act against the law. Drug abuse is a process that progressively increases from the stage of trial and error to the level of use for entertainment, site use, regular use to addiction.
\end{abstract}

\begin{tabular}{lr}
\hline Alamat korespondensi: & ISSN 2252-7133 \\
Gedung C4 Jurusan Pendidikan Kewarganegaraan & E-ISSN 2548-4648 \\
Universitas Negeri Semarang & \\
E-mail: natalkristiono@mail.unnes.ac.id &
\end{tabular}




\section{PENDAHULUAN}

Penyalahgunaan narkoba menjadi masalah yang belum bisa teratasi. Banyak kasus yang menggambarkan makin mengerikannya masalah tersebut. Untuk menyelesaikan masalah penyalahgunaan narkoba tidak hanya bisa diselesaikan oleh salah satu pihak saja. Saat ini banyak pihak baik dari pemerintah, mahasiswa, maupun LSM yang telah menyuarakan dan peduli dengan masalah narkoba ini namun ini belum bisa mengatasi permasalahan tersebut. Penyalahgunaan narkoba ini memang seperti fenomena gunung es yang kelihatannya sudah habis namun dalam dasarnya masih banyak, bila dihadapkan dengan kenyataan yang ada masalah penyalahgunaan ini memerlukan perhatian khusus. Peningkatan penyalahgunaan narkoba di Indonesia semakin mengkhawatirkan dengan dampak ekonomi dan sosial yang semakin besar pula. Dari hasil penelitian BNN dan Puslitkes UI tahun 2005 menyatakan bahwa kerugian ekonomi dan sosial penyalahgunaan narkoba tahun 2004 diperkirakan Rp. 23,6 triliun dengan prevalensi jumlah penyalahgunaan 2,9 juta hingga 3,6 juta orang atau setara 1,5\% penduduk indonesia. Dalam survei nasional penyalahgunaan dan peredaran gelap narkoba pada kelompok rumah tangga di Indonesia tersebut, juga disimpulkan bahwa penyalahgunaan narkoba sudah sampai di rumah tangga dan terkonsentrasi pada kelompok generasi penerus (BNN,2007b:1). Mencermati kondisi tersebut maka diperlukan pembekalan pengetahuan bagi remaja tentang bahaya penyalahgunaan narkoba, sehingga mereka bisa menjadi sumber informan yang baik dan benar serta mampu mendidik teman-temannya dalam menhindarkan diri dari penyalahgunaan narkoba.

Mencegah penyalahgunaan dan peredaran gelap narkoba bukan upaya yang mudah. Permasalahan yang sangat kompleks, dan melibatkan beberapa faktor yang kompleks pula. Penyalahgunaan narkoba dapat menimpa siapa saja, akan tetapi ada orang yang mempunyai resiko yang lebih tinggi untuk menyalahgunanakan narkoba bila dibandingkan dengan rata-rata penduduk. Masa remaja cenderung rawan menggunakan narkoba. Masa remaja adalah masa peralihan dari kanak-kanak ke dewasa. Terjadi perubahan yang pesat secara biologis, Psikologis, dan sosial. Perkembangan fisik menyamai orang dewasa, namun emosinya belum dapat mengikuti perkembangan fisik yang pesat itu. Keterbatasan cara pandangnya menyebabkan remaja sulit menunda pemuasaan keinginan seketika, karena itu remaja lebih mirip anak kecil yang berbadan besar daripada orang dewasa. Itu sebabnya remaja rawan terhadap stres dan frustasi, sehingga rawan menyalahgunakan narkoba. Ciri remaja yang ingin tahu dan ingin mencoba juga dapat menjadi penyebab remaja menyalahgunakan narkoba karena penggunaan narkoba biasanya bermula dari rasa ingin tahu, ingin mencoba, dan agar diterima oleh lingkungannya (BNN,2007b:47). Remaja juga senang melakukan hal-hal yang mengandung resiko, seperti ngebut, merokok, dan mencoba narkoba. Ciri lain dari remaja adalah setia dengan kelompok sebayanya. Remaja merasa ada keterikatan atau keberasamaan dengan kelompok sebayanya. Ada kebudayaan remaja, yaitu kesamaan dalam berpakaian, berbicara, bahasa, hobi, serta sikap dan perilaku. Ada kecenderungan remaja tidak mau berbeda dengan kelompok sebayanya, sebab ia ingin diterima dan diakui oleh kelompoknya. Kelompok remaja berperan penting sebagai teman senasib, partner, atau saingan. Melalui kehidupan kelompok remaja dapat berperan, bereksperimen, dan mengekspresikan dirinya. Ia ingin diterima dalam segala bentuk keberhasilan dan kegagalan. Jika kelompok sebaya memiliki nilai-nilai positif, maka perkembangan remaja pun positif. Namun Jika kelompok sebaya memiliki nilai negatif maka remaja ada kemungkinan terjerumus kepada berbagai perbuatan berbahaya dan tidak bertanggung jawab (BNN, 2007: 49). Oleh karena itu remaja harus mampu memilih dan memutuskan nilainilai yang baik dan positif bagi dirinya demi masa depan dirinya. Penyalahgunaan narkoba mengancam generasi muda kita terutama anak usia remaja, disini yang sungguh mengkhawatirkan adalah kebanyakkan diusia ini anak memperoleh pendidikan sekolah yang kemudian bisa dikatakan sebagai seorang pelajar. 


\section{METODE}

Penentuan obyek penelitian dimaksudkan untuk mempermudah atau memperlancar obyek yang menjadi sasaran dalam penelitian sehingga permasalahannya tidak telalu luas dan umum. Adapun lokasi penelitian ini adalah sekolah yang berada di kabupaten Pemalang dengan mengambil sample secara random. Adapun sample yang dilakukan dalam penyusunan artikel ini antara lain SMA/SMK negeri dan Swasta, SMP negeri dan Swasta.

Sesuai dengan rumusan permasalahan dan tujuan penelitian, maka yang menjadi fokus penelitian adalah peranan komunitas pelajar anti narkoba dalam upaya penanggulangan bahaya narkoba. Personal Personal dalam penelitian ini meliputi Instansi terkait, guru dan siswa. Prosedur disini adalah upaya dan mekanisme yang diterapkan oleh pihak sekolah dalam melaksanakan upaya penanggulangan bahaya narkoba.

Menurut Lor Land, menyatakan bahwa sumber data utama dalam penelitian kualitatif adalah kata- kata dan tindakan, selebihnya ialah data tambahan seperti dokumen dan lain-lain. (Moleong, 2002: 112). Responden merupakan orang yang merespon atau menjawab pertanyaan-pertanyaan peneliti (Arikunto, 2002:198). Dalam penelitian ini yang menjadi responden adalah Siswa SMK Texmaco Pemalang.

Informan dalam penelitian ini adalah Pimpinan Sekolah dan Jajaran Guru Pembina STP2K, siswa. Moleong (2002:90) dalam hal ini memberikan dua cara untuk dapat menemukan informan yaitu melalui keterangan orang yang berwenang baik secara formal ataupun informal, serta melalui wawancara pendahuluan yang dilakukan oleh peneliti.

\section{PEMBAHASAN}

Ketika berbicara narkotika, isu yang terus berhembus di Indonesia adalah penyalahgunaannya untuk kesenangan pribadi, bukan medis, yang rawan berujung pada tindakan kriminal lainnya. Penyalahgunaan narkotika dan obat-obat berbahaya di Indonesia beberapa tahun terakhir ini menjadi masalah serius dan telah mencapai masalah keadaan yang memperihatinkan sehingga menjadi masalah nasional. Korban penyalahgunaan narkoba telah meluas sedemikian rupa sehingga melampaui batas-batas strata sosial, umur, jenis kelamin Merambah tidak hanya perkotaan tetapi merambah sampai pekelurahanan dan melampaui batas negara yang akibatnya sangat merugikan perorangan, masyarakat, negara, khususnya generasi muda. Bahkan dapat menimbulkan bahaya lebih besar lagi bagi kehidupan dan nilai-nilai budaya bangsa yang pada akhirnya dapat melemahkan ketahanan nasional.

Pengertian penyalahgunaan adalah menggunakan kekuasaan dan sebagainya tidak sebagaimana mestinya. Dengan menyalahgunakan sesuatu baik itu kekuasaan, benda dan lain sebagainya, seseorang ingin mendapatkan sesuatu yang menurut mereka dapat menguntungkan mereka. Penyalahgunaan narkotika yang dilakukan seseorang dapat diartikan menggunakan narkotika tidak sebagaimana mestinya, dalam hal ini tentunya di luar pengawasan seorang dokter. Terjadinya penyalahgunaan di dalam masyarakat tentunya sangat mempengaruhi masyarakat itu sendiri. Pengaruh itu bisa berupa pengaruh terhadap ketenangan dalam masyarakat, pengaruh terhadap timbulnya kejahatan dalam masyarakat dan sebagainya.

Demikian juga dengan penyalahgunaan narkotika di kalangan remaja, dapat mempengaruhi keadaan dan lingkungan disekitarnya, baik itu lingkungan keluarga, lingkungan pergaulan dan masyarakat di tempat tinggal mereka. Dalam lingkungan keluarga dapat membuat orang tua mereka cemas serta terjadi perselisihan. Dalam lingkungan pergaulan seorang pencandu narkotika dapat mempengaruhi teman-teman bergaul mereka untuk mencoba merasakan yang namanya narkotika, sedangkan di dalam masyarakat terjadinya penyalahgunaan narkotika dapat menimbulkan kecemasan dan rasa takut bagi masyarakat karena adanya penyalahgunaan narkotika dapat menimbulkan kejahatan. 
Kejahatan tersebut dapat berupa pencurian, perampokan, pemerasan dan bahkan pembunuhan. Bagi mereka yang menyalahgunakan narkotika termasuk orang yang mampu, mungkin tidak akan terlalu menimbulkan pengaruh terhadap masyarakat disekitarnya, tapi bagi mereka yang tidak mampu dapat menimbulkan kejahatan karena harga narkotika tergolong mahal sehingga mereka akan berusaha untuk memenuhi ketergantungan mereka dengan cara apapun. Yaitu dengan melukai diri, menjual barang milik sendiri untuk mendapatkan narkotika, atau bahkan menjual barang milik orang lain.

Dalam dunia medis narkotika sangat diperlukan untuk pembiusan dalam menjalankan operasi pembedahan, karena salah satu kegunaan dari narkotika adalah menghilangkan rasa sakit, sehingga dengan memberikan narkotika pada pasien maka di dalam menjalankan operasi pembedahan si pasien tidak akan merasakan sakit. Adanya narkotika itu sendiri tidak dilarang karena sangat diperlukan untuk kepentingan pengobatan. Hal ini dapat dilihat dengan digunakannya dan dibutuhkannya candu sebagai obat mulai puluhan tahun yang lalu, bahkan kebutuhan tersebut menunjukkan grafik meningkat. Meningkatnya candu ini bukan saja digunakan sebagai obat tetapi juga disalahgunakan untuk mendapatkan efek atau pengaruh dari pemakaian narkotika tersebut.

Narkoba (Narkotika, psikotropika dan obat-obatan terlarang) merupakan salah satu penyebab penurunan kualitas SDM Indonesia yang secara tidak langsung menghambat pembangunan nasional. Ketersediaan narkoba bisa bermanfaat sebagai obat dan pengembangan ilmu pengetahuan. Tetapi di sisi lain dapat menimbulkan ketergantungan yang sangat merugikan apabila dipergunakan tanpa pengendalian dan pengawasan yang ketat dan seksama. Penyalahgunaan narkoba bukan hal baru di Indonesia. Kasus penyalahgunaan narkoba, khususnya obat-obatan terlarang, mengalami peningkatan setiap tahun. Penyalahgunaan obat-obatan terlarang tidak hanya terjadi di Kota Besar di Indonesia.
Penyalahgunaan obat-obatan terlarang juga marak terjadi di daerah.

Penyalahgunaan narkoba tentunya mempunyai dampak negatif, baik bagi pengguna maupun orang lain di sekitar lingkungan pelaku karena dapat mengakibatkan efek domino lainnya, yaitu tindakan kriminal yang mengikuti. Ada dua macam sifat ketergantungan yaitu sifat ketergantungan jasmaniah (physical independence) atau kecanduan dan sifat ketergantungan kejiwaan (psychological dependence) atau kebiasaan. Untuk pengguna itu sendiri, narkotika yang disalahgunakan oleh setiap individu dapat membawa efek-efek negatif terhadap tubuh si pemakai itu sendiri baik fisik, psikis, maupun sosial.

Penyalahgunaan narkotika saat ini bukan lagi berhubungan dengan gengsi tetapi motivasinya sudah dijadikan semacam tempat pelarian. Akhir-akhir ini penyalahgunaan narkotika tidak saja menjadi kendala di kota-kota besar tetapi mulai meramba ke kelurahankelurahan. Selama ini yang melakukan penyalahgunaan narkotika berasal dari keluarga yang dianggap mampu. Penyalahgunaan narkotika bukan lagi sebagai lambang kejantanan, keberanian, modern dan lain-lain tetapi motivasinya telah dikaitkan dengan pandangan yang lebih jauh dan ketergantungan serta dijadikan pelarian karena frustasi dan kecewa.

Bangsa Indonesia, saat ini sedang dihadapkan pada keadaan yang sangat mengkhawatirkan akibat semakin maraknya penggunaan narkotika, kekhawatiran ini semakin dipertajam akibat meluasnya peredaran narkotika di kalangan generasi muda. Selain itu Indonesia yang beberapa waktu lalu menjadi tempat transit dan pasar bagi peredaran narkotika, saat ini sudah berkembang menjadi produsen narkotika.

Hal ini berdasarkan pernyataan beberapa narasumber bahwa narkoba pada pelajar digunakan sebagai salah satu sarana Having Fun. Pelajar beranggapan bahwa setelah mengkonsumsi narkotika tersebut efek yang dirasakan adalah badan merasa kuat ketika berada di tengah persoalan yang dihadapi. Latar 
belakang tersebut yang menyebabkan penggunaan narkotika pada pelajar baik secara sadar maupun tidak masih sangat tinggi. Faktor penyebab tingginya penyalahgunaan narkotika pada pelajar adalah kemudahan pelajar dalam mendapatkan barang tersebut. Pelajar dapat membeli beberapa jenis narkoba dengan harga yang terjangkau dan dapat memperolehnya dari rekan pengguna maupun pengedar.

Ancaman bahaya penyalahgunaan Narkoba di kalangan pelajar Kabupaten Pemalang tentunya menimbulkan kepedulian dari Sekolah untuk mengambil langkah mengantisipasi dan menghindarkan peserta didik atau pelajar di Kabupaten Pemalang dari bahaya penyalahgunaan Narkoba. Disadari bahwa penyalahgunaan Narkoba memang sudah mengincar generasi muda kita yaitu pelajar, sehingga Sekolah harus peka dan peduli dengan penyalahgunaan Narkoba bagi pelajar. Untuk dapat mencegah pelajar menyalahgunakan Narkoba BNK Pemalang berkoordinasi dengan Dinas Pendidikan Kabupaten Pemalang yang kemudian dilanjutkan dengan mengintruksikan kepada Sekolah-Sekolah untuk peduli dan berupaya melakukan upaya penanggulangan penyalahgunaan Narkoba. Dari data yang diperoleh jumlah sekolah dengan rincian SD Negeri sejumlah 718, SD swasta sebanyak 29. Untuk SMP Negeri Sejumlah 166 dan SMP swasta sebanyak 66. Sedangkan Untuk SMA Negeri sejumlah 23 dan swasta sejumlah 11 Sekolah. Adapun untuk SMK negeri sejumlah 4 dan swasta sebanyak 49 Sekolah. Dari sekian banyak Sekolah di kabupaten Pemalang yang selama ini aktif di dalam melakukan upaya penanggulangan penyalahgunaan Narkoba di kabupaten Pemalang adalah MAN Pemalang, SMK Texmaco Pemalang dan SMK PGRI 1 Taman. Sehingga yang menjadi kunci untuk mengatasi penyalahgunaan Narkoba di Kota Semarang adalah adanya kerjasama dari semua komponen baik pemerintah, pihak kepolisian, Sekolah dan masyarakat.

\section{KAPA Narkoba}

KAPA Narkoba (Kelompok Aksi Pelajar Anti Narkoba) adalah program yang disusun dan dikembangkan secara komprehensif dan terpadu di lingkungan sekolah, dengan membangun budaya antinarkoba, anti kekerasan, dan penegakan disiplin, untuk mencegah dan menanggulangi masalah penyalahgunaan narkoba dan kekerasan (BNK: 2006).

Tema kekerasan harus menjadi bagian terpadu dari upaya mencegah dan menanggulangi penyalahgunaan narkoba, terutama di lingkungan sekolah. Demikian juga penegakan disiplin, karena sekolah dengan tingkat penyalahgunaan narkoba rendah, memiliki disiplin yang tinggi. Kekerasan diartikan secara luas bukan semata-mata kekerasan secara fisik, melainkan dapat juga bersifat psikologis, misalnya mengancam, menteror, intimidasi, caci maki, dan sebagainya.

Program tersebut melibatkan seluruh komponen sekolah (siswa, personel sekolah, orang tua siswa, dan tokoh masyarakat) dengan dukungan lembaga pelayanan kesehatan, sosial, agama, dan penegakan hukum, agar tercipta lingkungan sekolah bebas narkoba, sebagai bagian dari lingkungan masyrakat bebas narkoba.

Adapun prinsip program ini adalah Tujuan program adalah: (1) Mencegah dan mengurangi penyalahgunaan narkoba dan kekerasan, agar tercipta suasana belajar-mengajar yang kondusif di sekolah, dengan membangun norma (budaya) anti narkoba, anti kekerasan, dan penegakan disiplin; (2) Ruang lingkup masalah, meliputi penggunaan dan peredaran narkoba secara gelap, kekerasan dan pelanggaran disiplin sebagai suatu kesatuan yang tidak dapat dipisahkan. Sekolah dengan disiplin tinggi, jarang terlibat kekerasan atau penyalahgunaan narkoba; (3) Program di sekolah harus menjadi bagian dari program lingkungan/kelurahan/kecamatan bebas narkoba; (4) Melibatkan semua komponen sekolah (semua personel sekolah, siswa, orang tua, dan tokoh masyarakat); (5) Bersikap terbuka dan tidak menutup-nutupi adanya masalah. sikap tertutup mengurangi bahkan menghambat keberhasilan program; (6) Peraturan dan tata tertib harus berlaku adil dan diterapkan secara konsisten bagi semua komponen sekolah (siswa, guru, dan personel sekolah lain); (7) Melaksanakan program pendidikan pencegahan 
pada setiap jenjang usia secara berkesinambungan, baik dalam kegiatan kurikuler maupun ekstrakurikuler yang berorientasi pada keterampilan menolak tawaran (resistance skills), dan mengelola kehidupan sehari-hari (life skills), dengan sistem modul dan partisipasi siswa secara aktif; ( 8) Menyediakan layanan bimbingan dan konseling serta rujukannya; (10) Mempersiapkan sarana dan prasarana yang diperlukan, antara lain, organisasi, personel terlatih, pencatatan dan pelaporan, pedoman pelaksanaan, buku modul atau lembar kerja siswa; (11) Bekerja sama dengan instansi pelayanan kesehatan, sosial, dan agama, serta instansi penegak hukum.

\section{Upaya penanggulangan penyalahgunaan narkoba}

Penanggulangan artinya cara, proses, perbuatan menanggulangi (kamus besar bahasa indonesia: 2001). Penanggulangan narkoba adalah suatu cara atau upaya untuk menyelesesaikan masalah narkoba. Dalam melakukan pencegahan penyalahgunaan Narkoba bagi pelajar di Kabupaten Pemalang, KAPA Narkoba bersama sekolah dan instansi terkait telah melakukan kegiatan sebagai berikut:

a. Melakukan pendekatan dan sosialisasi kepada orang tua untuk memberikan bekal kepada mereka dalam melakukan pencegahan dini kepada anak agar tidak melakukan penyalahgunaan Narkoba, disini peran pengetahuan dari orang tua tentang penyalahgunaan Narkoba sangat penting untuk dapat membina anaknya, misalnya dengan memberikan pengetahuan dini mengenai penyalahgunaan Narkoba serta memberikan dasar-dasar nilai keagamaan kepada anak agar anak memiliki keimanan yang kuat sehingga sulit untuk dipengaruhi orang lain dan tidak melakukan tindakan negatif, salah satunya adalah penyalahgunaan Narkoba. Hal ini merupakan pola Pencegahan berbasis keluarga, meliputi : pemberdayaan keluarga rentan penyalahgunaan Narkoba, pengembangan partisipasi keluarga dalam upaya pencegahan penyalahgunaan Narkoba di lingkungannya, penyadaran keluarga melalui media massa.

b. Melakukan upaya pencegahan langsung yaitu mengurangi faktor-faktor yang mendorong timbulnya kesempatan atau peluang untuk melakukan penyalahgunaan dan peredaran gelap Narkoba dengan usaha menciptakan kesadaran, kepedulian, kewaspadaan, serta daya tangkal pelajar. Kegiatan ini dilakukan melalui sosialisasi dan pelatihan kepada pelajar. Kegiatan ini memberikan bekal kepada pelajar tentang pengetahuan dasar Narkoba, pemberian pengetahuan tentang bahaya ataupun akibat yang ditimbulkan, penguatan pribadi pelajar untuk dapat menghindarkan diri dari penyalahgunaan Narkoba. Selain itu juga dilakukan pola pencegahan berbasis Sekolah, dengan melakukan pendidikan tentang bahaya Narkoba, Pengembangan Sumber Daya Manusia berbasis Sekolah. Sasarannya : pelajar, guru, serta Kepala Sekolah.

c. Sekolah dalam melakukan pencegahan penyalahgunaan Narkoba melakukan kegiatan sidak setiap 4 bulan sekali, patroli keamanan dan pemasangan poster tentang bahaya Narkoba, lomba-lomba, pengisian artikel bebas Narkoba di majalah Sekolah, serta mengadakan penyuluhan yang semuanya dikoordinir oleh KPS-KAPA Narkoba. KPS-KAPA Narkoba juga sebagai organisasi pengamanan Sekolah dari bahaya Narkoba dan rokok menjadi program kerja Sekolah dalam memberantas Narkoba.

d. Sekolah menetapkan peraturan yang ketat terhadap siswanya, yaitu dengan mengambil langkah pemberian skors dan tentunya akan dilakukan sharing kepada orang tua/ wali murid untuk mengatasi permasalahan yang dihadapi siswa tersebut. Didalam melakukan pengawasan untuk menghindarkan siswa menyalahgunakan Narkoba di lingkungan Sekolah, KPS-KAPA Narkoba selalu melakukan patroli keamanan setiap hari dan juga menerima pengaduan masalah pelanggaran tata tertib Sekolah.

e. Sekolah menyediakan fasilitas yang memadai bagi siswa untuk menyalurkan 
bakat ataupun hobi agar siswa dapat memanfaatkan waktu luang untuk hal-hal yang positif. Fasilitas itu seperti Lapangan voli, Lapangan basket, Lapangan futsal, Laboratorium IPA, Laboratorium bahasa, Perpustakaan, Ruang musik, ekstra tari. Sekolah juga melakukan pengembangan kegiatan ekstrakulikuler di Sekolah sebagai pengisi waktu luang.

f. Pencegahan melalui penciptaan lingkungan awal yang bebas dari penyalahgunaan Narkoba yaitu melalui calon siswa yang ingin mendaftar sebagai salah satu syarat pendaftaran harus menunjukkan surat kelakuan baik dari Sekolah mereka sebelumnya. Hal ini untuk membangun lingkungan Sekolah ataupun lingkungan antar siswa yang baik, karena pengaruh teman sebaya sangat besar terhadap penciptaan lingkungan yang bebas dari penyalahgunaan Narkoba.

g. Di dalam mencegah pelajar melakukan tindakan yang negatif Sekolah juga menyedikan suatu layanan Bimbingan dan Konseling kepada siswa yang bermasalah, sehingga siswa dapat meminta bantuan BK untuk dapat membantu menyeleseikan masalah yang dialami oleh pelajar sehingga hal ini dapat menekan keinginan pelajar untuk menyelesaikan masalah dengan melakukan tindakan yang negatif serta dapat membantu mengatasi permasalahan yang dialami oleh siswa, sehingga hal ini menjadi suatu langkah mensukseskan program penanggulangan penyalahgunaan Narkoba bagi pelajar.

h. Melakukan upaya promotif yang dilaksanakan berupa kegiatan penyebaran informasi yang tepat, terpercaya, obyektif, dan mudah dimengerti tentang penyalahgunaan dan peredaran gelap Narkoba, kegiatan pembinaan dan pengembangan lingkungan masyarakat bebas Narkoba, pembinaan dan pengembangan pola hidup sehat dan beriman kepada TYME serta kegiatan positif, produktif, konstruktif dan kreatif. Upaya promotif ini juga dengan memberikan bimbingan teknis kepada guru-guru sehingga mereka dapat memberikan informasi yang benar serta mampu membina siswanya agar terhindar dari penyalahgunaan Narkoba. Selain itu dilakukan pengembangan kualitas Sumber Daya Manusia (SDM) dengan tujuan meningkatkan kualitas kemampuan SDM bidang pencegahan. Kegiatannya, antara lain : pengiriman aparatur pemerintah dan masyarakat mengikuti pendidikan/penataran, sosialisasi seminar, lokakarya tingkat Nasional, menjadi instruktur/fasilitator. Kegiatan promotif ini juga meliputi kegiatan sosialisasi dan promosi Pencegahan, Pemberantasan Penyalahgunaan dan Peredaran Gelap Narkoba (P4GN) yang mempunyai tujuan meningkatkan pengetahuan masyarakat tentang pencegahan penyalahgunaan Narkoba. Kegiatannya antara lain : Pemasangan iklan layanan masyarakat, olah raga bersama, pentas seni/hiburan, pemutaran film, ceramah, siaran radio, talk show, pemasangan spanduk, penyebaran panflet/stiker/kalender, serta menerbitkan buku tentang penanggulangan penyalahgunaan Narkoba.

i. Melakukan upaya komunikasi, informasi dan edukasi meliputi kegiatan pendidikan Sekolah maupun luar Sekolah, dengan sasaran guru/tenaga pendidik dan peserta didik baik kurikuler maupun ekstrakuler; Lembaga keagamaan dengan sasaran pemuka-pemuka agama dan umatnya; Organisasi sosial kemasyarakat dengan sasaran remaja/ pemuda dan potensi masyarakat; media massa baik elektronik, cetak, maupun interpersonal (talkshow dan dialog interaktif), dengan sasaran masyarakat secara luas maupun individu.

j. Melakukan pencegahan berbasis komunitas, meliputi : Pendidikan keterampilan hidup sehat (program PKK), penyadaran masyarakat akan bahaya Narkoba. Sasarannya : PKK, RT/RW, karang taruna, kelompok interaktif Masyarakat (KIM), Forum Informasi Masyarakat (FIM), Lembaga Pemberdayaan Masyarakat 
Kelurahan) serta pencegahan kepada pelajar melalui pengaktifan KPS-KAPA Narkoba (Kelompok Pemuda Sebaya-Kelompok Pelajar Anti Narkoba) di Sekolah dan meningkatkan kepedulian penanggulangan penyalahgunaan Narkoba kerjasama Sekolah dengan Badan Komite Sekolah.

k. Melakukan pencegahan berbasis masyarakat agar masyarakat sadar, peduli dan aktif dalam melakukan pencegahan terhadap penyalahgunaan dan peredaran gelap Narkoba. Untuk mendorong peran serta masyarakat dalam rangka pencegahan penyalahgunaan Narkoba kegiatannya yaitu memfasilitasi kerjasama kegiatan. Kegiatan yang dilakukan untuk meningkatkan kepedulian dan partisipasi masyarakat dalam menanggulangi penyalahgunaan Narkoba bagi pelajar kegiatannya meliputi : pertunjukan olahraga dan seni, Lomba mewarnai, pameran Anti Narkoba, sepeda ria, senam massal dan jalan sehat, festival musik, lomba kreasi anak, sarasehan, donor darah, light on, sepeda ria anti Narkoba .

\section{SIMPULAN}

Berdasarkan pembahasan diatas dapat disimpulkan bahwa penyalahgunaan narkoba dikalangan pelajar dipengaruh oleh faktor internal, eksternal dan ketersediaan narkoba. KAPA Narkoba menjadi salah satu unsur penting sebagai wadah pembinaan pelajar supaya tidak terjerumus dalam penyalahgunaan narkoba. Masih tingginya angka penyalahgunaan narkoba dikalangan pelajar menjadi tantangan kedepan untuk KAPA Narkoba. Perlu Mensinergikan instansi-instansi terkait untuk mendukung upaya-upaya yang telah dilakukan oleh KAPA Narkoba di kabupaten Pemalang.

\section{DAFTAR PUSTAKA}

Badan Narkotika Nasional. (2004a). Peran Remaja Dalam Mengatasi Masalah Penyalahgunaan Narkotika. Jakarta: BNN

Badan Narkotika Nasional (2004b). Pedoman Pencegahan Penyalahgunaan Narkoba Bagi Pemuda. Jakarta:BNN

Badan Narkotika Nasional. (2007). Hasil-Hasil Penelitian Penyalahgunaan Dan Peredaran Gelap Narkoba Di Indonesia Tahun 2006 dan 2007.

Penelitian.Jakarta:PUSLITBANGINFO BNN

Moleong, Lexyi. (2002). Metodologi Penelitian Kualitatif, Bandung: PT. Remaja Rosdakarya.

Kristiono, Natal. Dkk (2017) Strategi Pencegahan Penyalahgunaan Narkoba Di Kalangan Nelayan ( Studi Kampung Nelayan Di Desa Widuri dan Tanjungsari Kabupaten Pemalang). Jurnal Integralistik 28 (1), 68-80.

Kristiono, Natal, Indri Astuti (2019). Kita Muda, Stop Narkoba! Kenikmatan Sesaat Membuatmu Sengsara. Makasar : Mentari Jaya.

Kristiono, Natal. (2018). Pentingnya Peran Pendidikan Dalam Mencegah Bahaya Narkoba. Makasar: Mentari Jaya.

Kristiono, Natal. (2018) Pengembangan Metode Tutor Teman Sebaya Sebagai Upaya pencegahan Penyalahgunaan Narkoba Pada Pelajar. Jurnal Integralistik 29 (2), 6777. 